\title{
Effects of seasonal dynamics in a Zostera noltii meadow on phosphorus and iron cycles in a tidal mudflat (Arcachon Bay, France)
}

\author{
Jonathan Deborde $^{1, *}$, Gwenaël Abril ${ }^{1}$, Aurélia Mouret ${ }^{1}$, Didier Jézéquel ${ }^{2}$, \\ Gérard Thouzeau ${ }^{3}$, Jacques Clavier ${ }^{3}$, Guy Bachelet ${ }^{4}$, Pierre Anschutz ${ }^{1}$ \\ ${ }^{1}$ Université Bordeaux 1, CNRS, UMR 5805 Environnements et Paléoenvironnements Océaniques (EPOC), \\ Avenue des Facultés, 33405 Talence, France \\ ${ }^{2}$ Université Paris 7 \& IPGP, CNRS, UMR 7047 Laboratoire de Géochimie des Eaux (LGE), 2 Place Jussieu, \\ 75251 Paris Cedex 05, France
}

${ }^{3}$ Institut Universitaire Européen de la Mer, CNRS, UMR 6539 Laboratoire des Sciences de l'Environnement Marin (LEMAR), Technopôle Brest-Iroise, Place N. Copernic, 29280 Plouzané, France

${ }^{4}$ Université Bordeaux 1, CNRS, UMR 5805 Environnements et Paléoenvironnements Océaniques (EPOC), Station Marine d'Arcachon, 2 Rue du Professeur Jolyet, 33120 Arcachon, France

\begin{abstract}
A study was conducted in Arcachon Bay, France, to determine the effect of seasonal dynamics in a Zostera noltii meadow on $\mathrm{P}$ and Fe cycles in the superficial sediments of a tidal mudflat. The redox-sensitive Fe particulate pool and associated P in the root zone showed a seasonal variation following the growth and decay of $Z$. noltii biomass, with a maximum content during the growth period. In comparison, the bare sediments did not show significant seasonal changes. A dissolved inorganic phosphorus (DIP) uptake was measured from the water column to the sediment in vegetated sediments, whereas a net DIP efflux was observed in the unvegetated sediments. During the growth period, the formation of an iron oxihydroxide-rich zone occurred and acted as a trap for dissolved phosphorus, constituting a reserve of available P for eelgrass growth. At the periphery of the rhizosphere, a strong reduction of the sediment occurred during the growth phase, probably due to increasing organic matter inputs via the roots. The iron oxihydroxide dissolution releases Fe(II) and the recently bound phosphorus to the pore water, making it available for assimilation by the eelgrass roots for growth metabolism. Fe(II) is re-oxidized to solid Fe(III) forms depleted in P into the root zone, or re-precipitated below as sulphur forms. The highest P uptake occurs by this process, and the seasonal variations in redox-sensitive $\mathrm{P}$ stock are sufficient to support the annual $Z$. noltii $\mathrm{P}$ requirement. During the decline period, as the P plant demand and the oxic layer thickness drop, the unused released DIP pool supplies large amounts of DIP to the pore water and water column.
\end{abstract}

KEY WORDS: Nutrient $\cdot$ Eelgrass growth $\cdot$ Intertidal zone $\cdot$ Lagoon $\cdot$ Early diagenesis

\section{INTRODUCTION}

Eelgrass meadows are considered as valuable components of coastal environment because of their fundamental role in trophic webs, biogeochemical cycles, and sedimentary processes (Phillips \& Menez 1988, Hemminga 1998, Blanchet et al. 2004). The nutrients considered most limiting in meadow systems are nitro- gen and phosphorus, which constitute major metabolic and structural components of eelgrasses (Duarte 1990, Walker et al. 2004). Eelgrasses are capable of absorbing nutrients from both the sediment and the water column, but it is assumed that root uptake dominates over leaf uptake in environments where nutrients are higher in pore water than in surface water (McRoy et al. 1972, Hemminga 1998, Holmer et al. 2006). Occa- 
sionally, in P-rich waters or P-poor sediments, P uptake by leaves may exceed roots uptake (Perez-Llorens \& Niell 1995, Gras et al. 2003, Holmer et al. 2006). The losses of seagrass habitats are commonly associated with increased eutrophication and degradation of the light environment of meadows (Hemminga 1998, Azzoni et al. 2001).

Due to eutrophication, the enhancement of primary production in water increases organic matter fluxes to the sediment (Welsh et al. 2000). Eelgrasses also export via photosynthesis high amounts of organic carbon into the sediments through their root-rhizome system (Kaldy et al. 2006), which fuels bacterial benthic respiration. These mechanisms enhance organic matter mineralization, in particular sulphate reduction, which is the dominant carbon-oxidation pathway in coastal marine sediment (Jørgensen 1982, Canfield \& Thamdrup 1996). This induces anoxic conditions in the eelgrass rhizosphere and high sulphide production, which is toxic for seagrasses (Goodman et al. 1995, Lee \& Dunton 2000, Hebert \& Morse 2003). The oxygen diffusion from leaves towards the rhizome and roots helps to counteract the accumulation of free sulphides and to support their respiration. Part of this oxygen diffuses into the rhizosphere, where it strongly influences the diagenetic processes by reoxidation of reduced compounds, such as ammonium, dissolved metals, and sulphides (Isaksen \& Finster 1996, Hemminga 1998, Jensen et al. 2005). The reoxidation rate can be 20 times higher in the rhizosphere of eelgrass meadow than in unvegetated sediment (Sand-Jensen et al. 1982, Frederiksen \& Glud 2006). Thus, oxygen diffusion induces the formation of a $\mathrm{Fe}(\mathrm{III})$-rich sediment layer close to the roots (Sundby et al. 1998, 2003). This Fe-oxide layer influences the phosphate availability in the interstitial water due to its high adsorption degree by reactive iron oxides, in particular in siliclastic sediments (Jensen et al. 1995). In addition, iron oxides and dissolved iron can react with free sulphides and precipitate as $\mathrm{FeS}$ and $\mathrm{FeS}_{2}$ via a suite of redox reactions and remove free sulphides from the pore water (Azzoni et al. 2001, Hebert \& Morse 2003) and release the phosphorus associated with iron oxides (Jensen et al. 1995, Anschutz et al. 1998, 2007). The dissolved P availability is thus indirectly linked to sulphur and iron cycling. A fraction of the phosphate released in the sediment can successfully reach the rhizosphere and the water column, stimulating pelagic primary productivity and eelgrass growth. To replace the dissolved phosphate that escapes, the sediment can release adsorbed phosphate to pore water (Sundby et al. 1992).

Thus, iron cycling and consequently phosphorus cycling may be correlated with the seasonal dynamics in eelgrasses. In the present study, we describe the seasonal variations of phosphorus and iron distributions in sediment of a tidal mudflat in a temperate mesotidal bay, with emphasis on the annual dynamics in a Zostera noltii meadow. Biogeochemical parameters, such as mobile pools of $\mathrm{P}$ (dissolved inorganic $\mathrm{P}$ [DIP], Fe-bound P) and iron (dissolved reduced $\mathrm{Fe}$, reactive Fe-oxides), particulate carbon and sulphur were measured in sediment to investigate the effect of seasonal changes in eelgrass biomass on P dynamics. The effect of eelgrasses on these distributions was assessed by comparison with an unvegetated part of the tidal mudflat at each key period of the meadow development: end of winter, spring, summer, end of summer and beginning of winter. To map the iron distribution around the rhizosphere and in unvegetated sediment during the growth period, we also used gel probe techniques (Jézéquel et al. 2007). Fluxes of DIP across the sediment-water interface were also studied at high tide during the dormancy and growth periods using benthic chambers (Thouzeau et al. 2007).

\section{MATERIALS AND METHODS}

Study area. Sampling was carried out in Arcachon Bay, a $156 \mathrm{~km}^{2}$ mesotidal lagoon located on the French Atlantic coast $\left(44^{\circ} 40^{\prime} \mathrm{N}, 1^{\circ} 10^{\prime} \mathrm{W}\right)$. The tide is semi-diurnal and the tidal amplitude varies from 1.1 to $4.9 \mathrm{~m}$. Surface water temperature fluctuates annually between 1 and $25^{\circ} \mathrm{C}$, and surface water salinity between 22 and 32 . The landward part of the bay is affected by river inputs and underground freshwater discharges. At low tide, tidal channels drain large tidal flats $\left(115 \mathrm{~km}^{2}\right)$. Zostera noltii meadows cover $70 \mathrm{~km}^{2}$ of these tidal flats, while $Z$. marina occupies only $4 \mathrm{~km}^{2}$ (Auby \& Labourg 1996, Blanchet et al. 2004). Due to the low mudflat slope, the intertidal area is exposed to the atmosphere for several hours during each semi-diurnal tidal period. The investigated site is located in the inner part of the lagoon, on a tidal mudflat ('Cassy') drained at low tide by small tidal channels which are not connected to a river. The tidal flat is characterized by a $Z$. noltii-covered part, which was referred to as Stn Z, and an area free of macrophytes called Stn N.

Sampling procedures. Biogeochemical dynamics of phosphorus and iron were investigated in triplicate sediment cores manually collected at each station using acrylic tubes (10 cm diameter, $20 \mathrm{~cm}$ length), in March, May, July, September, and December 2006. Sampling was performed at low tide and at noon. Cores were immediately sliced with $0.5 \mathrm{~cm}$ resolution for the top $2 \mathrm{~cm}$, with $1 \mathrm{~cm}$ resolution in the 2 to $10 \mathrm{~cm}$ layer, and with $2 \mathrm{~cm}$ resolution down to the core bot- 
tom. During this slicing process, the penetration depth of eelgrass roots was visually determined. For each level, a sub-sample was sealed in a pre-weighted vial under inert $\mathrm{N}_{2}$ atmosphere and frozen for later chemical analyses of the solid fraction. Another sub-sample was centrifuged to extract pore water at $4000 \mathrm{rpm}$ $(2280 \times g)$ for $15 \mathrm{~min}$ under inert $\mathrm{N}_{2}$-atmosphere (to prevent oxidation), and filtered through acetate cellulose membrane $(0.2 \mu \mathrm{m}, \mathrm{MINISART})$. An aliquot of filtered interstitial water was immediately acidified to $\mathrm{pH}$ 1.6 with $\mathrm{HNO}_{3}$ to prevent precipitation of reduced dissolved iron. A second aliquot was refrigerated at $4{ }^{\circ} \mathrm{C}$ for DIP analysis. Eelgrass samples (5 replicates) were collected at Stn Z with randomly positioned cores (9.1 $\mathrm{cm}$ diameter, $15 \mathrm{~cm}$ length). The sediment slices were immediately washed on a sieve (1 $\mathrm{mm}$ mesh size). Zostera noltii individuals were well rinsed in the laboratory to remove salt and particles, and dried for $48 \mathrm{~h}$ at $70^{\circ} \mathrm{C}$ in order to estimate dry biomass (roots and leaves).

Gel and PVC probes. To improve our knowledge of iron and S(-II) sulphur dissolved species distributions in sediment pore waters, a device composed of a polyacrylamide gel thin-film $(18 \mathrm{~cm}$ high, $5 \mathrm{~cm}$ wide and $0.4 \mathrm{~mm}$ thick) and a PVC (polyvinyl chloride) film was used as a sediment probe, as described in Jézéquel et al. (2007). Probes were deployed in May 2006 for $4 \mathrm{~h}$ at low tide in the superficial sediment of vegetated and unvegetated sites. The polyacrylamide gel layer was used as a DET (Diffusive Equilibration in Thin-films) device for 2D (2-dimensional) Fe(II) concentration determination, and as the diffusive layer of a DGT-like (Diffusive Gradients in Thin-films) device for sulphur species study. The accumulation layer of the DGT device consisted of a PVC film layer beneath the polyacrylamide layer. Iron determinations were performed by colorimetric methods using the ferrozine and imaging technique (Jézéquel et al. 2007). Image acquisitions were performed with a flatbed scanner on the more representative gel-PVC probes. Fe(II) concentrations were deducted from densitometry analysis of the magenta zones (ImageJ software 1.31, available at: http://rsb. info.nih.gov/ij/). The calibration curve was obtained by densitometry analysis of polyacrylamide gel pieces which were equilibrated in known iron (II) concentration solutions. Analysis of grey zones on the PVC layer provided a qualitative distribution of unidentified S(-II)-dissolved compounds related to the $\mathrm{H}_{2} \mathrm{~S}$ zone.

Benthic chambers. Measurements of DIP fluxes at the sediment-water interface were performed using benthic chambers as described in Thouzeau et al. (2007). Three replicate acrylic tubes $\left(0.196 \mathrm{~m}^{2}\right)$ were gently pushed by SCUBA divers into the sediment in vegetated and unvegetated sites in March 2005 and
May 2006, when there was at least $80 \mathrm{~cm}$ of water on the mudflat. Acrylic hemispheres were secured to each base to trap a known volume of bottom water, varying from 36 to 501 according to base insertion into the substrate. A series of incubations were carried out for $1 \mathrm{~h}$ $20 \mathrm{~min}$ to $5 \mathrm{~h}$ in daylight (clear chambers: 6 incubations) and in dark conditions (opaque chambers: 9 incubations). Homogenization of water inside the enclosure was provided by adjustable submersible pumps connected to waterproof batteries. As metabloc responses depend on hydrodynamics (Forja \& GomezParra 1998), water flow in each enclosure was adjusted to the minimum value $\left(21 \mathrm{~min}^{-1}\right)$, allowing stable measurements to be recorded by the probes. Water samples were collected in the chambers for DIP analysis at the beginning and end of the incubations using $500 \mathrm{ml}$ polyethylene syringes. Outside water was admitted through a tap during sampling to avoid interstitial water release from the sediment. DIP concentrations were measured on a Technicon Autoanalyser II according to Tréguet \& Le Corre (1975).

Core laboratory analysis. Dissolved inorganic phosphate and iron were measured in interstitial waters by colorimetric procedures 1 or $2 \mathrm{~d}$ after sampling with a precision of $\pm 5 \%$ (Murphy \& Riley 1962, Stookey 1970, Strickland \& Parsons 1972). Sediment was freeze-dried and the weight loss was used to calculate water content after sea salt correction. The dried sediment was homogenized and kept for solid-phase analysis. An ascorbate reagent (57 $\mathrm{mM}$ ascorbic acid + $85 \mathrm{mM} \mathrm{Na}_{3}$ citrate + $298 \mathrm{mM} \mathrm{NaHCO}$, pH = 8) was added to remove the most reactive Fe (III) phases $\left(\mathrm{Fe}_{\mathrm{asc}}\right)$ and the associated phosphorus $\left(\mathrm{P}_{\mathrm{asc}}\right)$ from the sediment (Kostka et al. 1994, Anschutz et al. 1998). $\mathrm{Fe}_{\text {asc }}$ can partly result from the oxidation of FeS during sample freeze-drying. A separate extraction was carried out with $1 \mathrm{M} \mathrm{HCl}$ to determine acid-soluble iron $\left(\mathrm{Fe}_{\mathrm{HCl}}\right)$. This reagent was used to dissolve amorphous Fe oxides, FeS, Fe phyllosilicates and carbonates (Kostka et al.1994). Phosphorus extracted with $\mathrm{HCl}\left(\mathrm{P}_{\mathrm{HCl}}\right)$ came from detrital and authigenic phosphate minerals, and from carbonates (Kostka et al. 1994, Anschutz et al. 2007). For both extractions, about $100 \mathrm{mg}$ of dry sample was leached with $10 \mathrm{ml}$ solution during $24 \mathrm{~h}$ while shaking continuously at room temperature. After each extraction, the samples were centrifuged and the Fe and P contents of the supernatant were determined spectrophotometrically using, as previously, the ferrozine and molybdate methods, in a mixture of reagents adapted for each sample matrix. Blank solutions were made with the leaching solutions and experienced the same treatment as the samples. The precision estimated from replicates was $\pm 5 \%$ for $\mathrm{P}$ and $\pm 7 \%$ for Fe. Particulate organic carbon (POC), total carbon, and total sulphur (TS) were measured on freeze-dried samples by 
infrared spectroscopy using a LECO C-S 125 gas chromatography analyser. POC was measured after removal of carbonates with $2 \mathrm{M} \mathrm{HCl}$ from $50 \mathrm{mg}$ of powdered sample. Particulate inorganic carbon (PIC) is the difference between total carbon and POC. The precision of these analyses was $\pm 0.01 \%$ dry weight (DW).

\section{RESULTS}

\section{Zostera noltii biomass and field observations}

Sediment from Stns Z and N consisted of silty-mud material with $62 \pm 5 \%$ of water content and was rich in organic matter (Table 1). The sediment surface was colonized by large numbers of the mud snail Hydrobia ulvae. Other abundant infauna included the oligochaete Tubificoides benedii, polychaetes (Aphelochaeta marioni, Heteromastus filiformis, Melinna palmata, Pygospio elegans, Streblospio shrubsolii), and bivalves (Abra tenuis, Tapes philippinarum), which heavily bioturbated the top layers of sediment. In the winter period (December to March), the Zostera noltii meadow was limited to a root-rhizome web, which colonized only the top $2 \mathrm{~cm}$ sediment layer in December and the top $4 \mathrm{~cm}$ layer in March. Except for a thin brown layer at the surface, the whole sediment column was grey-black, with numerous microzones reduced (darker), and released a strong odour of hydrogen sulphides. Similar observations were noted in the bare site for the same period. Organic carbon content, which was the main particulate carbon, was not significantly higher at Stn Z than at Stn N. At the beginning of the growth period, eelgrass biomass drastically increased, as shoots and leaves developed, from $22.9 \mathrm{~g}$ DW m${ }^{-2}$ in March to $135.2 \mathrm{~g} \mathrm{DW} \mathrm{m}^{-2}$ in May (Table 1). During summer, the meadow regularly grew to reach $377.3 \mathrm{~g} \mathrm{DW} \mathrm{m}^{-2}$ in September, and declining rapidly in
December (26.9 $\mathrm{g} \mathrm{DW} \mathrm{m}^{-2}$ ). During the growth season, the root system developed and colonized the sediment down to a depth of $6 \mathrm{~cm}$, and an irregular red-grey layer developed (between 1 and $6 \mathrm{~cm}$ ). The development of eelgrasses did not significantly increase the sediment organic carbon content compared with unvegetated sediments. POC concentrations were ca. 3.1 to $3.8 \%$ in the root zone of Stn Z vs. 3.1 to $3.5 \%$ at Stn N. However, a strong gradient in TS content appeared at $\operatorname{Stn} Z$, between the upper sediments and underlying sediments (Table 1). In the deeper section, TS content was always higher at Stn Z than at Stn N, where it was constant over the whole sediment column ( 2.37 to $2.96 \%$, maximum in September).

\section{Phosphorus and iron profiles}

\section{Spatial heterogeneity}

Intertidal sediments are known to be very heterogeneous because of their high degree of bioturbation (Hemminga et al. 1994, Leuschner et al. 1998, Lillebo et al. 2006), which complicates the interpretation of profiles. This spatial heterogeneity in the vegetated and bare sediment was investigated by making 3 replicate depth profiles of iron and phosphorus in 3 cores separated from each other by a distance of ca. $1.5 \mathrm{~m}$ (Figs. 1 \& 2). Spatial heterogeneity of chemical species is commonly presented as the standard deviation (SD)

Fig. 1. Distributions of (a-e) dissolved inorganic phosphorus (DIP), (f-j) $\mathrm{Fe}^{2+},(\mathrm{k}-\mathrm{o})$ ascorbate phosphorus $\left(\mathrm{P}_{\mathrm{asc}}\right)$ and phosphorus extracted with $\mathrm{HCl}\left(\mathrm{P}_{\mathrm{HCl}}\right),(\mathrm{p}-\mathrm{t})$ ascorbate $\mathrm{Fe}\left(\mathrm{Fe}_{\mathrm{asc}}\right)$ and iron extracted with $\mathrm{HCl}\left(\mathrm{Fe}_{\mathrm{HCl}}\right)$ in sediments from the unvegetated part of the tidal mud flat (Stn N) collected in March, May, July, September and December 2006. $\bullet$ : Replicate 1 ; O: Replicate $2 ; \mathrm{x}$ : Replicate 3

Table 1. Sediment characteristics of the 2 study sites (Stns Z and N) and total biomass of Zostera noltii at Stn Z (mean \pm SD; $\mathrm{n}=5$ ). For Stn $Z$, the values are arithmetic means of sub-samples taken from the 3 replicate cores for the section integrating the root maximum penetration depth ( $\mathrm{n}=9$ to 21 ) and for underlying sediments $(\mathrm{n}=24$ to 36$)$. For $\mathrm{Stn} N$, the values are arithmetic means on the whole cores $(3$ replicates, $n=45$ ). Samples were collected in March, May, July, September and December 2006. n: number of core subsamples; DW: dry weight; POC: particulate organic carbon; PIC: particulate inorganic carbon; TS: total particulate sulphurs

\begin{tabular}{|c|c|c|c|c|c|c|c|c|c|c|}
\hline \multirow[t]{3}{*}{ Month } & \multirow{3}{*}{$\begin{array}{l}\text { Biomass } \\
\left(\mathrm{g} \mathrm{DW} \mathrm{m}^{-2}\right)\end{array}$} & \multirow{2}{*}{\multicolumn{3}{|c|}{ Stn Z - }} & \multirow{3}{*}{\multicolumn{2}{|c|}{$\begin{array}{c}\text { - Sediment }(\%) \\
\text { PIC }\end{array}$}} & \multirow[b]{3}{*}{ TS } & \multirow{2}{*}{\multicolumn{3}{|c|}{$\begin{array}{c}\text { Stn } \mathrm{N} \\
\text { Whole core }(\%)\end{array}$}} \\
\hline & & & & & & & & & & \\
\hline & & POC & PIC & TS & & & & POC & PIC & TS \\
\hline $\operatorname{Mar}^{\mathrm{a}}$ & $22.9( \pm 15.2)$ & $3.83( \pm 0.30)$ & $0.25( \pm 0.22)$ & $1.81( \pm 0.29)$ & $3.44( \pm 0.23)$ & $0.20( \pm 0.23)$ & $2.58( \pm 0.39)$ & $3.09( \pm 0.61)$ & $0.12( \pm 0.16)$ & $2.37( \pm 0.60)$ \\
\hline May $^{b}$ & $135.2( \pm 17.6)$ & $3.51( \pm 0.28)$ & $0.41( \pm 0.33)$ & $1.80( \pm 0.32)$ & $3.42( \pm 0.33)$ & $0.30( \pm 0.26)$ & $2.49( \pm 0.42)$ & $3.45( \pm 0.32)$ & $0.18( \pm 0.36)$ & $2.34( \pm 0.38)$ \\
\hline $\mathrm{Jul}^{\mathrm{b}}$ & $272.4( \pm 110.1)$ & $3.28( \pm 0.74)$ & $0.36( \pm 0.46)$ & $2.33( \pm 0.61)$ & $3.43( \pm 0.24)$ & $0.21( \pm 0.30)$ & $2.67( \pm 0.34)$ & $3.15( \pm 0.37)$ & $0.20( \pm 0.38)$ & $2.71( \pm 0.39)$ \\
\hline $\mathrm{Sep}^{\mathrm{b}}$ & $377.3( \pm 97.5)$ & $3.09( \pm 0.30)$ & $0.26( \pm 0.29)$ & $2.19( \pm 0.45)$ & $3.30( \pm 0.23)$ & $0.15( \pm 0.29)$ & $3.06( \pm 0.42)$ & $3.18( \pm 0.35)$ & $0.09( \pm 0.14)$ & $2.96( \pm 0.47)$ \\
\hline $\operatorname{Dec}^{c}$ & $26.9( \pm 8.4)$ & $3.22( \pm 0.37)$ & $0.11( \pm 0.21)$ & $2.62( \pm 0.73)$ & $3.42( \pm 0.27)$ & $0.30( \pm 0.34)$ & $3.43( \pm 0.85)$ & $3.23( \pm 0.34)$ & $0.10( \pm 0.13)$ & $2.50( \pm 0.48)$ \\
\hline
\end{tabular}




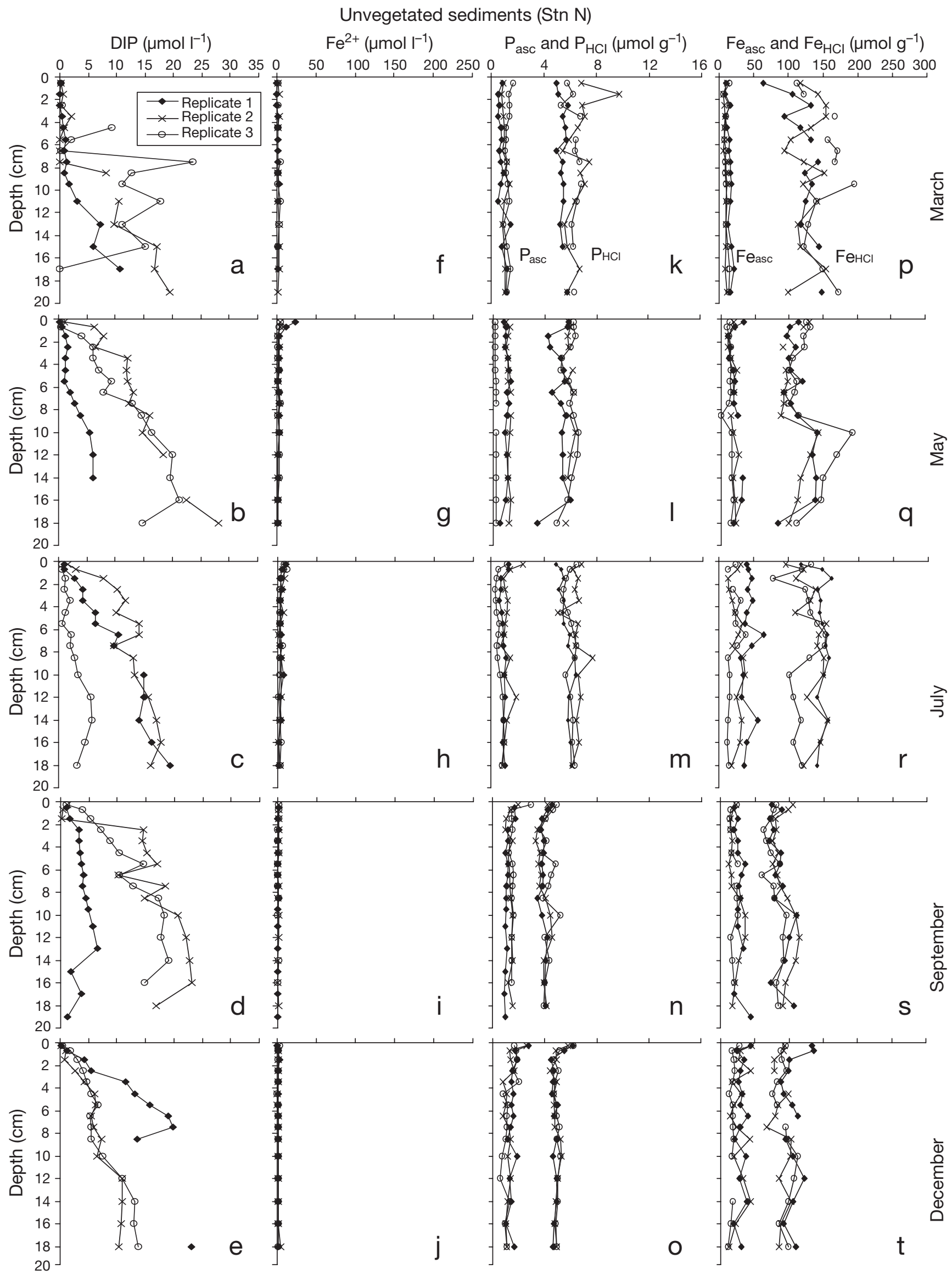


Vegetated sediments (Stn Z)

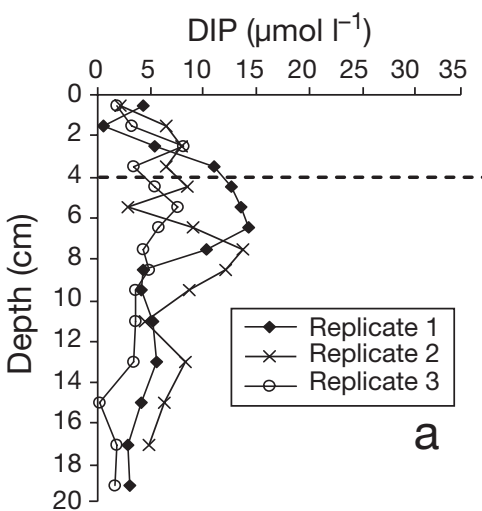

$\mathrm{Fe}^{2+}\left(\mu \mathrm{mol}{ }^{-1}\right) \quad \mathrm{P}_{\mathrm{asc}}$ and $\mathrm{P}_{\mathrm{HCl}}\left(\mu \mathrm{mol} \mathrm{g}^{-1}\right) \quad \mathrm{Fe}_{\mathrm{asc}}$ and $\mathrm{Fe}_{\mathrm{HCl}}\left(\mu \mathrm{mol} \mathrm{g}{ }^{-1}\right)$
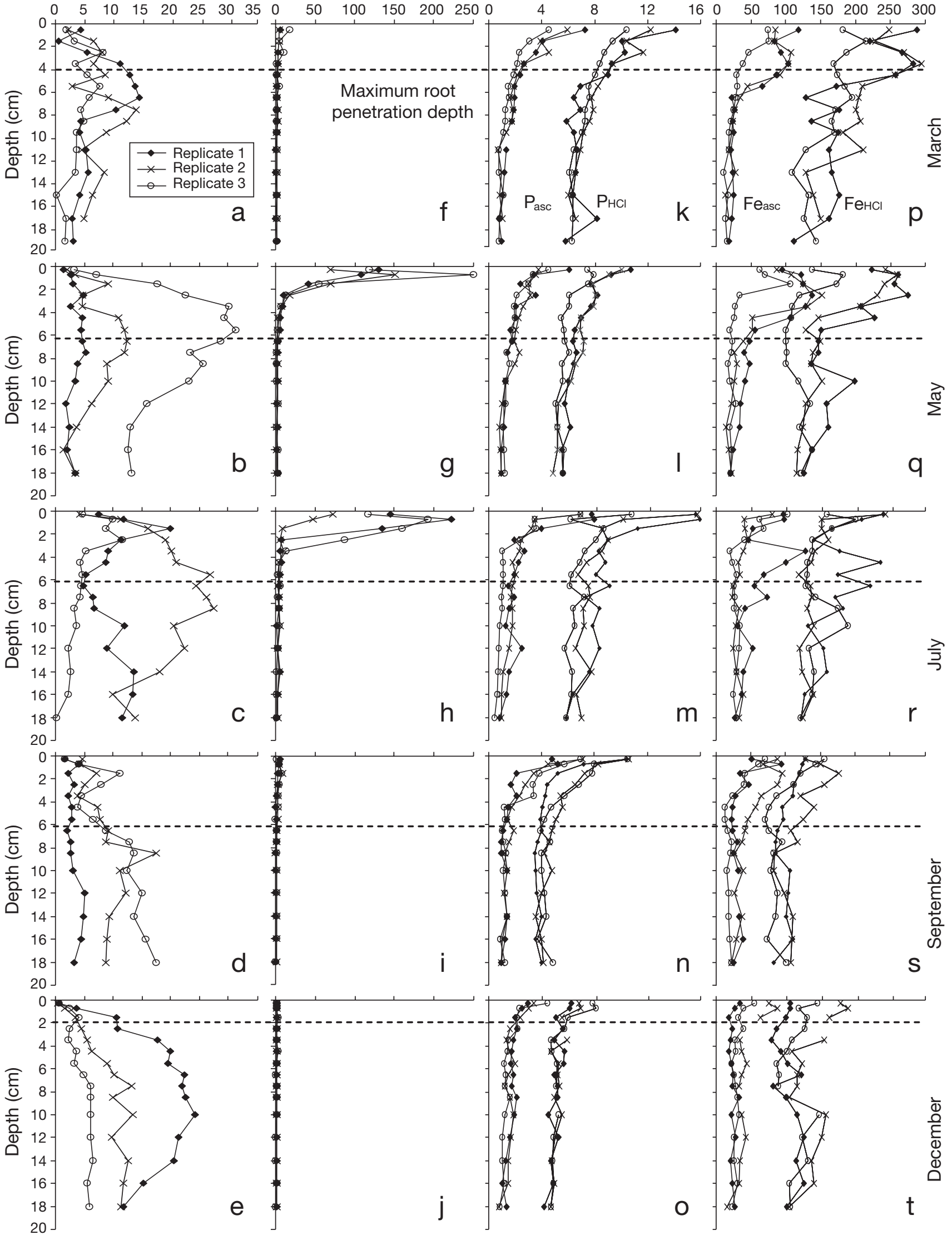
Fig. 2. Distributions of (a-e) dissolved inorganic phosphorus (DIP), (f-j) $\mathrm{Fe}^{2+},(\mathrm{k}-\mathrm{o})$ ascorbate phosphorus $\left(\mathrm{P}_{\mathrm{asc}}\right)$ and phosphorus extracted with $\mathrm{HCl}\left(\mathrm{P}_{\mathrm{HCl}}\right),(\mathrm{p}-\mathrm{t})$ ascorbate $\mathrm{Fe}\left(\mathrm{Fe}_{\mathrm{asc}}\right)$ and iron extracted with $\mathrm{HCl}\left(\mathrm{Fe}_{\mathrm{HCl}}\right)$ in sediments from the Zostera noltii-covered part of the tidal mud flat (Stn Z) collected in March, May, July, September and December 2006. Dashed horizonal lines indicate maximum penetration depth of eelgrass roots for each sampling period. $\bullet$ : Replicate 1 ; O: Replicate $2 ; x$ : Replicate 3

from the average concentration of the 3 replicate profiles vs. depth (Hebert \& Morse 2003). According to our calculations on SD (data not shown), spatial heterogeneity was more pronounced within the root zone, particularly during the growth period (May to September), when the root-rhizome system was established, especially for the dissolved fraction, whereas the unvegetated cores show a lower degree of vertical variation (Fig. 1). During winter, a decrease in pore water heterogeneity occurred in vegetated sediment below the root zone and SD values were similar to those found in the unvegetated sediment. This high heterogeneity noted at Stn Z was probably also due to differences in macrophytes biomass between the sampling cores. Moreover, it has been demonstrated that species richness of macrofauna is higher in meadows than in unvegetated sediment because of a strong affinity of macrofauna for eelgrass (Blanchet et al. 2004). Thus, the bioturbation was more intense in vegetated sediment and reinforces the direct effect of Zostera noltii to create a high spatial heterogeneity.

\section{Unvegetated sediment}

From one sampling period to the next, chemical species profiles were very similar in the unvegetated sediment (Fig. 1). The DIP concentrations were below $1 \mu \mathrm{mol} \mathrm{l} \mathrm{l}^{-1}$ in the top $1 \mathrm{~cm}$ and increased regularly with

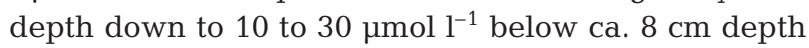
(Fig. 1a-e). The concentrations of dissolved iron were very low (3 to $5 \mu_{\mathrm{mol} \mathrm{l}} \mathrm{l}^{-1}$ ) and constant in the whole cores, except in May and July, when a slight peak of about $25 \mu \mathrm{mol} \mathrm{l}^{1}$ occurred in the top $2 \mathrm{~cm}$ (Fig. 1g,h). The content of ascorbate and $\mathrm{HCl}$ extractable $\mathrm{P}$ and $\mathrm{Fe}$ was stable throughout the entire cores. In March and May, particulate $\mathrm{P}$ values were close to 1 and $2 \mu \mathrm{mol}$ $\mathrm{g}^{-1}$, and 4 and $5.5 \mu \mathrm{mol} \mathrm{g}{ }^{-1}$ for $\mathrm{P}_{\mathrm{asc}}$ and $\mathrm{P}_{\mathrm{HCl}}$, respectively. In July, September and December, particulate $\mathrm{P}$ concentrations showed a slight enrichment in superficial sediment (3 and $7 \mu \mathrm{mol} \mathrm{g}^{-1}$ for $\mathrm{P}_{\mathrm{asc}}$ and $\mathrm{P}_{\mathrm{HCl}}$, respectively), but were constant deeper in the core (1.5 and $4 \mu \mathrm{mol} \mathrm{g}^{-1}$ for $\mathrm{P}_{\mathrm{asc}}$ and $\mathrm{P}_{\mathrm{HCl}}$, respectively; Fig. $1 \mathrm{~m}-\mathrm{o}) \cdot \mathrm{Fe}_{\mathrm{asc}}$ concentrations ranged from 25 to $45 \mu \mathrm{mol} \mathrm{g}^{-1}$ over time, showing higher content of
$\mathrm{Fe}_{\mathrm{HCl}}$ in March, May and July (generally 100 to $150 \mu \mathrm{mol} \mathrm{g}^{-1}$, Fig. 1p-r) than in September and December (generally 70 to $100 \mathrm{mmol} \mathrm{g}^{-1}$, Fig. 1s,t).

\section{Vegetated sediment}

Profiles of the chemical species showed large temporal and spatial variations (Fig. 2). DIP concentrations did not show a spatial and temporal trend below the root zone. A significant decrease in DIP concentrations was observed in the root zone toward the sediment surface. For example, DIP concentrations decreased from 15-20 $\mathrm{\mu mol} \mathrm{l}^{-1}$ at $4 \mathrm{~cm}$ depth to $0.2-1 \mu \mathrm{mol} \mathrm{l}^{-1}$ below the interface in winter (Fig. 2a,e). During the growth period, the depletion was more pronounced, with DIP decreasing from 5-32 $\mu \mathrm{mol} \mathrm{l^{-1 }}$ at $6 \mathrm{~cm}$ depth to $1-4 \mu \mathrm{mol} \mathrm{l}^{-1}$ near the sediment-air interface (Fig. 2b,c). In March, $\mathrm{Fe}^{2+}$ concentrations showed a slight decrease from the first centimeters $\left(6-18 \mu \mathrm{mol} \mathrm{l^{-1 }}\right)$ down to $4 \mathrm{~cm}(1-3 \mu \mathrm{mol}$ $\mathrm{l}^{-1}$ ), and remained constant below that depth (Fig. 2f). In May and July, high values (70 to $250 \mu \mathrm{mol} \mathrm{l}^{-1}$ ) of dissolved iron were observed in the top $2 \mathrm{~cm}$ (Fig. 2g,h). In December, the concentrations were below $2 \mu \mathrm{mol} \mathrm{l}^{-1}$ and constant in the whole cores (Fig. 2j). The 3 replicate cores studied for particulate analyses exhibited maximum concentrations of ascorbate and $\mathrm{HCl}$ extractable $\mathrm{P}$ and $\mathrm{Fe}$ in the upper root zone (Fig. $2 \mathrm{k}-\mathrm{t}$ ). Particulate $\mathrm{P}$ decreased from the sediment surface to the zone of maximum root content depth from $4-8 \mu \mathrm{mol} \mathrm{g}^{-1}$ to $1-2 \mu \mathrm{mol} \mathrm{g}^{-1}$ for $\mathrm{P}_{\mathrm{asc}}$ and from 11-16 $\mu \mathrm{mol} \mathrm{g}{ }^{-1}$ to $6-9 \mu \mathrm{mol} \mathrm{g}{ }^{-1}$ for $\mathrm{P}_{\mathrm{HCl}}$, and were constant below that zone. Phosphorus extracted with $\mathrm{HCl}$ comes from the fraction extracted with ascorbate, with an additional contribution of igneous, biogenic or authigenic phosphate minerals (Ruttenberg 1992). $\mathrm{P}_{\mathrm{HCl}}$ distributions had shapes similar to those of $\mathrm{P}_{\mathrm{asc}}$ with highest values, suggesting that the $\mathrm{P}_{\mathrm{HCl}}$ profile came from the $\mathrm{P}_{\mathrm{asc}}$ fraction, with the addition of detrital igneous and biogenic phosphate contents, which were constant in the cores. The content of ascorbate Fe increased during growth of Zostera noltii in the 2 to $4 \mathrm{~cm}$ sediment horizon from 75 to $115 \mu \mathrm{mol} \mathrm{g}{ }^{-1}$ in March to 60-140 $\mu_{\mathrm{mol} \mathrm{g}}{ }^{-1}$ in May (Fig. 2p,q). From July to December, the Fe ${ }_{\text {asc }}$ content was lower and decreased from the interface (ca. $100 \mu \mathrm{mol} \mathrm{g}^{-1}$ ) to the root maximum penetration depth (ca. $45 \mu \mathrm{mol} \mathrm{g}{ }^{-1}$; Fig. $2 \mathrm{r}-\mathrm{t}$ ). Below the root zone, Fe $\mathrm{asc}_{\mathrm{ac}}$ content was always constant and similar to that mea-

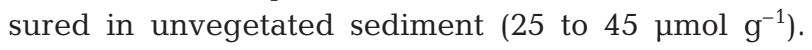
The distribution of $\mathrm{Fe}_{\mathrm{asc}}$ was consistent with the assumption that the ascorbate reagent extracted only poorly crystalline oxides (Kostka et al. 1994). Fe $\mathrm{Fsc}_{\mathrm{asc}}$ content was highest near the surface and decreased 

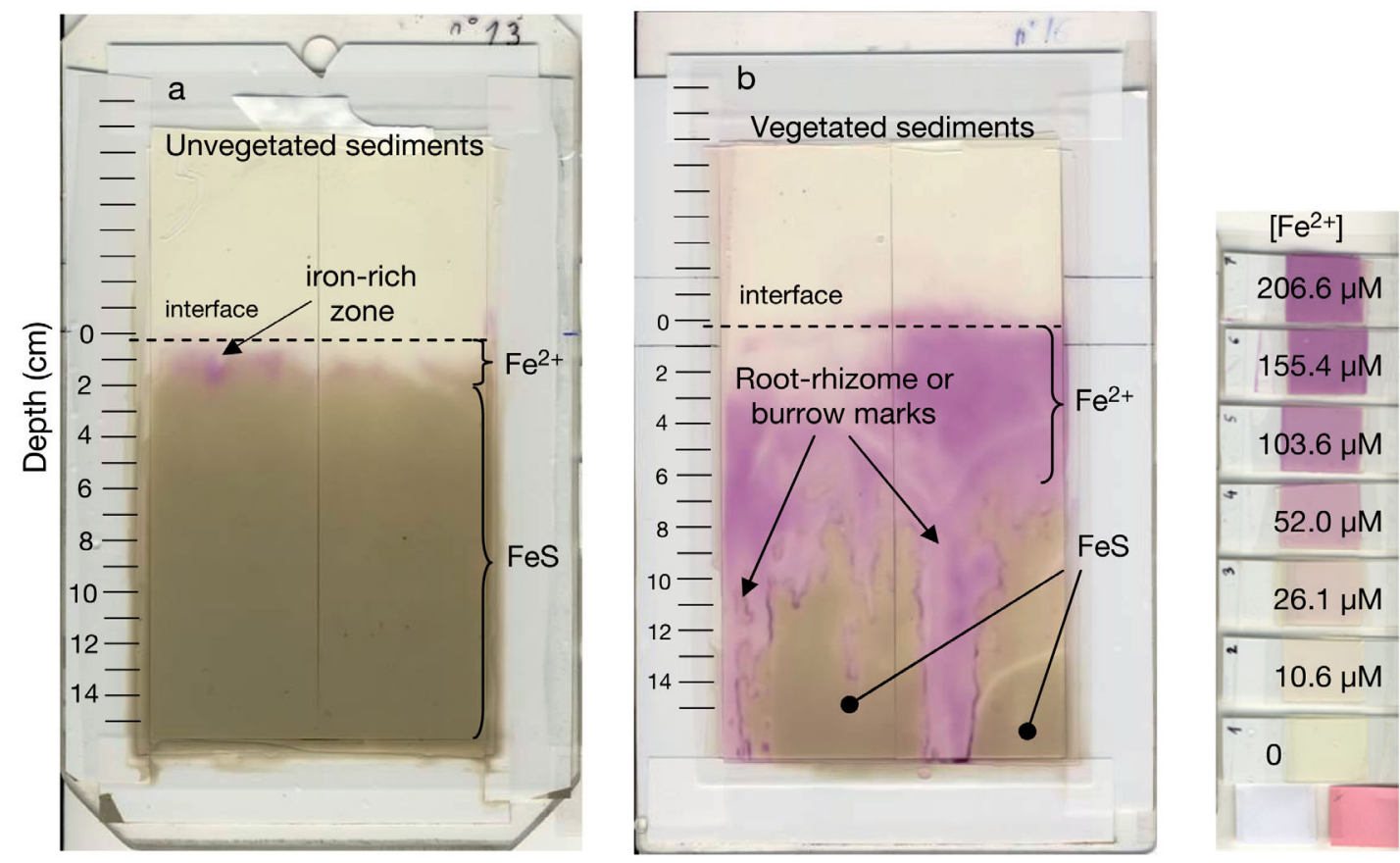

Fig. 3. 2D probes from (a) unvegetated sediment and (b) vegetated sediment in May 2006 (growth period) after a 12 min exposure to a ferrozine gel layer. Magenta: dissolved iron (II) distributions; light brown: sulphur distributions

below the oxic zones. $\mathrm{Fe}_{\mathrm{HCl}}$ concentrations showed similar profiles with higher values than $\mathrm{Fe}_{\mathrm{asc}}$, suggesting that seasonal variations in the particulate fraction were only due to variations in the ascorbate pool.

\section{D distribution of iron}

Iron and sulphur 2D probes collected during the eelgrass growth period in vegetated sediments (Fig. 3a) and bare sediments (Fig. 3b) were scanned 12 min after reaction with ferrozine. The magenta zones correspond to dissolved Fe(II)-rich zones, while the light brown zones indicate FeS-rich layers. In unvegetated sediments, high dissolved iron zones were located mainly near the sediment-water interface. They constituted small spots (less than $1 \mathrm{~cm}^{2}$ ) in the top $1 \mathrm{~cm}$. Below, a homogeneous zone of FeS dominated. The vegetated site was characterized by an extended zone of dissolved Fe reaching from the sediment-air interface to $6 \mathrm{~cm}$ depth as measured on sediment cores (Fig. $2 g$ ). As shown by our SD calculations, this layer was marked by high vertical heterogeneities, probably due to the presence of burrows and root-rhizome systems. The FeS zone appeared immediately below the limit of root penetration depth. FeS distribution was also heterogeneous with the development of structures linked to the root-rhizome web, which were probably swept downward during the $2 \mathrm{D}$ probe installation.

\section{DIP benthic fluxes}

At high tide, DIP benthic fluxes showed significant differences between the vegetated and unvegetated sites (Fig. 4) and large seasonal variations. On vegetated sediments, a DIP efflux (46.3 $\mu \mathrm{mol} \mathrm{m} \mathrm{m}^{-2} \mathrm{~d}^{-1}$ ) was measured in March 2005, but there was a large uptake in May $2006\left(-46.0 \mu \mathrm{mol} \mathrm{m} \mathrm{m}^{-2} \mathrm{~d}^{-1}\right)$. On unvege-

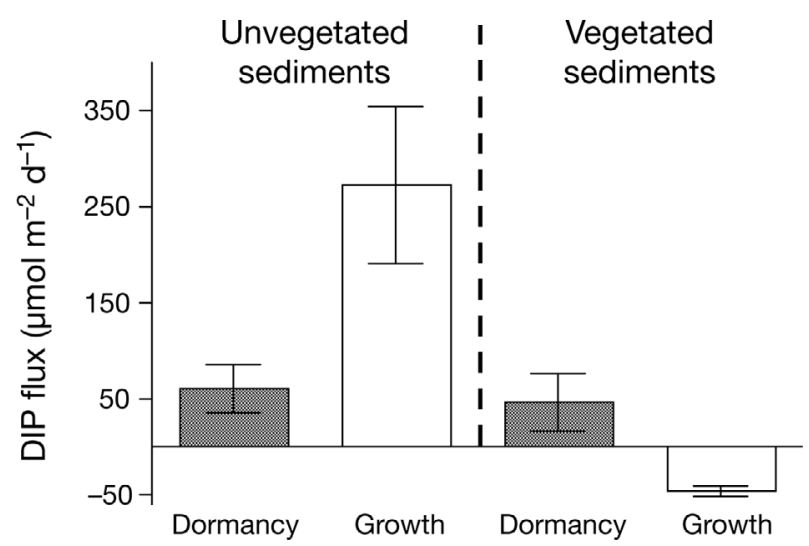

Fig. 4. Mean benthic fluxes of dissolved inorganic phosphorus (DIP) in Stn N (unvegetated sediments) and Stn Z (vegetated sediments) in March 2005 (Zostera noltii dormancy period) and May 2006 (growth period). Positive fluxes are oriented toward the water column, negative fluxes toward the sediment. Error bars indicate SDs calculated from dark $(n=9)$ and clear $(n=6)$ chamber experiments. DIP benthic fluxes were measured around high tide in daylight conditions 
tated sediments, there was a high DIP efflux in March $2005\left(60.4 \mu \mathrm{mol} \mathrm{m}{ }^{-2} \mathrm{~d}^{-1}\right)$ and May 2006 (272.5 $\mu_{\mathrm{mol} \mathrm{m}}{ }^{-2}$ $\mathrm{d}^{-1}$ ). The high standard deviations associated with the mean fluxes emphasized small-scale spatial heterogeneity (less than $3 \mathrm{~m}$ separated 2 successive replicate chambers).

\section{DISCUSSION}

In Arcachon Bay, eelgrasses are perennial and their biomass typically follows the seasonal variations of temperature and light, with net growth during spring and net loss during winter (Perez-Llorens \& Niell 1993, Auby \& Labourg 1996, Azzoni et al. 2001). The Zostera noltii meadow showed a classical growth curve during spring and summer with a rate of 1.7 to $2.3 \mathrm{~g} \mathrm{DW} \mathrm{m}^{-2} \mathrm{~d}^{-1}$ and reached a maximal biomass at the end of summer (Table 1). Because of a warm and sunny autumn in 2006, the meadows were maintained until November, but declined rapidly at the beginning of winter. During winter, the root-rhizome web remained in the top 2 to $4 \mathrm{~cm}$ of the sediments. However, the organic carbon content did not exhibit any significant differences between the meadow and bare sediments, which is in agreement with Holmer et al.'s (2006) results in Lillebælt sound. Stns $\mathrm{Z}$ and $\mathrm{N}$ are located in the inner bay at shallow depth (0.8 to $1.2 \mathrm{~m}$ ), and resuspension events may homogenize the detritus pools and minimize the difference between the 2 study sites. Future studies on particle dynamics in the Arcachon Bay will examine this hypothesis. The results obtained in the present study also show that the presence of macrophytes has a major effect on sediment biogeochemistry in the root zone as observed for Spartina or Thalassia species meadows (Oremland \& Taylor 1977, Sundby et al. 1998, Lee \& Dunton 2000, Gribsholt \& Kristensen 2002, Lillebo et al. 2006). The effect is mainly pronounced during the growth phase, whereas no significant difference could be noted between bare and vegetated sediments during the rest of the year or below the root zone (Figs. $1 \& 2$ ).

\section{Iron and phosphorus dynamics in the root zone}

At the end of winter dormancy, Zostera noltii initiates a new growth cycle and begins to produce new roots. The root zone sediment is then anoxic, as in unvegetated stations, with high concentrations of free sulphides or iron sulphides. During the growth period, the new roots infiltrate the anoxic sed- iment for nutrient uptake (DIP and DIN), and more oxygen is available in the root zone than is needed for plant and microbe respiration (Isaksen \& Finster 1996, Madureira et al. 1997). Oxygen in excess diffuses across the root tips to the interstitial water, where it seasonally reacts with reduced sediment components (Sundby et al. 1998, 2003). These latter studies on Spartina maritima and $Z$. marina showed that 2 distinct environments develop on a vertical scale during root growth: transient oxic microzones at the root vicinity, and a deeper anoxic sediment with redox conditions similar to those of unvegetated sediments. Previous studies on seagrasses (Smith et al. 1988, Hemminga 1998, Jensen et al. 2005) and the present study suggest that the same phenomena occur at a smaller scale in $Z$. noltii meadows. As reduced iron is present in interstitial water, oxygen diffusion into the root zone induces the formation of an important reactive oxide iron-rich layer in the sediment adjacent to the root zone (Fig. 2). Because of the rapid consumption of oxygen by the oxidation of Fe(II) to Fe(III) (Sundby et al. 2003), this iron oxide horizon develops quickly from the point in March when the first new roots penetrate the sediment (Fig. 2p,q). These iron hydroxides and oxihydroxides have a strong adsorption capacity for P (Anschutz et al. 1998, Cha et al. 2005). They rapidly store DIP from the pore waters and also from the water column as revealed by the high $\mathrm{P}_{\mathrm{asc}}$ concentrations in the first $6 \mathrm{~cm}$ of the rhizosphere (Fig. 2k,l) and the high DIP fluxes towards the vegetated sediments at high tide (Fig. 4). Iron oxides precipitated in the root zone thus constitute a huge trap of DIP and a potential reservoir of $\mathrm{P}$ available for eelgrass growth (Table 2, $\mathrm{Fe}_{\mathrm{asc}}: \mathrm{P}_{\mathrm{asc}}=$ 21 in March). Moreover, oxygen release is accompanied by an export of labile organic matter into the sediment via the root-rhizome web and eelgrass detritus (Kaldy et al. 2006, Papadimitriou et al. 2006). Dissolved

Table 2. Mean ratios $( \pm \mathrm{SD})$ of ascorbate extractable Fe vs. ascorbate extractable $\mathrm{P}$ in the sediments and dissolved reduced iron vs. dissolved inorganic phosphorus (DIP) in pore water from Zostera noltii meadows (Stn Z) and unvegetated sediments (Stn N) in Arcachon Bay. Mean values are indicated for the root zone, underlying sediments (Stn Z), or the whole core (Stn N). An additional mean ratio was calculated from the ratios found in Thau lagoon and the continental margin and slope sediments for comparison (Anschutz et al. 1998, Cha et al. 2005). PP: particulate pool; DP: dissolved pool

\begin{tabular}{|c|c|c|c|c|c|c|c|}
\hline \multirow[t]{3}{*}{ Month } & \multicolumn{4}{|c|}{ Vegetated sediment } & \multirow{2}{*}{\multicolumn{2}{|c|}{$\begin{array}{l}\text { Unvegetated sediment } \\
\text { Whole core }\end{array}$}} & \multirow{3}{*}{$\begin{array}{l}\text { Marine } \\
\text { sediments }\end{array}$} \\
\hline & \multicolumn{2}{|c|}{ Root zone } & \multicolumn{2}{|c|}{ Sediment } & & & \\
\hline & PP & DP & $\mathrm{PP}$ & DP & PP & DP & \\
\hline Mar & $21( \pm 4)$ & $2( \pm 1)$ & $20( \pm 2)$ & $1( \pm 1)$ & $12( \pm 3)$ & $1.5( \pm 1)$ & \\
\hline May & $32( \pm 3)$ & $14( \pm 4)$ & $21( \pm 4)$ & $1( \pm 1)$ & $16( \pm 2)$ & $4( \pm 4)$ & \\
\hline Jul & $26( \pm 8)$ & $7( \pm 7)$ & $20( \pm 10)$ & $1( \pm 1)$ & $24( \pm 8)$ & $2( \pm 2)$ & $10( \pm 4)$ \\
\hline Sep & $18( \pm 7)$ & $1( \pm 1)$ & $22( \pm 5)$ & $1( \pm 1)$ & $16( \pm 6)$ & $1( \pm 1)$ & \\
\hline Dec & $17( \pm 2)$ & $2( \pm 1)$ & $20( \pm 4)$ & $1( \pm 1)$ & $19( \pm 4)$ & $1( \pm 1)$ & \\
\hline
\end{tabular}


organic carbon pools in pore water increase with increasing plant density (Smith et al. 1988), which enhances bacterial activity. Thus, during the growth phase and photosynthesis, increasing anoxic respiration processes may occur at the periphery of the rhizosphere. The early diagenesis induces reduction of the iron oxides, which may release high loads of dissolved iron and associated phosphorus. The molar $\mathrm{Fe}_{\mathrm{asc}}: \mathrm{P}_{\mathrm{asc}}$ ratio in the root zone increased to 32 in May (26 in July, Table 2). These ratios are lower than those found in marine sediments (Anschutz et al. 1998, Cha et al. 2005), which reveals the occurrence of sorption processes and an unsaturation of iron oxides with phosphorus within the root zone. As for dissolved reduced iron, this phosphorus should be found in interstitial water. However, no significant change was observed in DIP concentrations in the rhizosphere, while a peak in reduced iron was found (Fig. $2 b, c, g, h$ ). The Fe:P ratio of pore water increased from 2 in March to 14 in May ( 7 in July), suggesting a fast assimilation of the released DIP by eelgrass roots for the growth processes, inducing the low DIP concentrations noted in the high root density zone, and a stimulated iron reduction. The dissolved iron re-precipitates to Fe(III) oxides under oxic conditions (Fig. 2r,s) and can readsorb DIP. Similar patterns have been found in other studies during the growth period, where the DIP pool in the root zone of eelgrass meadows was lower than in unvegetated sediment, thus reflecting an uptake by the plants (Azzoni et al. 2001, McGlathery et al. 2001, Holmer et al. 2006). Below the rhizosphere, Fe(II) is exposed to a reduced environment, and precipitates as FeS and possibly pyrite (Fig. 3). This hypothesis is supported by the gel probes, while previous studies propose that excretion of organic matter directly from the plants also results in high sulphides concentrations by enhancing sulphate reduction (Blackburn et al. 1994, Isaksen \& Finster 1996, Holmer \& Nielsen 1997). In unvegetated sediments, iron oxide reduction induces a high DIP efflux (Fig. 4). From the end of summer to winter, the meadow rapidly declines due to light competition at high tide, irradiance decrease, and lethal effects associated with the fast sulphide accumulation (Auby \& Labourg 1996, Hemminga 1998, Azzoni et al. 2001). Organic matter inputs to the sediment gradually increase, whereas the oxygen supply to the sediment by the roots and nutrient uptake by the plants decrease. An intensification of anaerobic processes should occur, including iron oxide and sulphate reduction. Indeed, in Ruppia cirrhosa meadows Azzoni et al. (2001) observed the presence of highly reducing conditions and high sulphide concentrations in the pore water of the root zone in the period prior to the biomass decay. The iron oxide layer and root zone thickness drop, and dissolved reduced iron rapidly reacts with the reduced sulphur to form an increasing pool of precipitated reduced sulphides (Table 1) (Holmer \& Nielsen 1997). This should induce a DIP efflux from vegetated sediments during autumn and winter. Sedimentary P pools and Fe:P ratios in the reactive particulate phase and dissolved phase decrease and reach constant values similar to those measured in unvegetated sediments (Table 2).

\section{Available P stock and Zostera noltii dynamics}

Perez-Llorens \& Niell $(1993,1995)$ determined phosphorus uptake rates by leaves and roots of about $100 \mu \mathrm{mol} \mathrm{P} \mathrm{g} \mathrm{DW}{ }^{-1} \mathrm{~d}^{-1}$ for Zostera noltii during the growth period. The investigated meadow showed an average growth rate of $2.1 \mathrm{~g} \mathrm{DW} \mathrm{m}^{-2} \mathrm{~d}^{-1}$ from March to September. This corresponds to a daily average theoretical $\mathrm{P}$ requirement of about $209 \mu \mathrm{mol} \mathrm{P} \mathrm{m}{ }^{-2} \mathrm{~d}^{-1}$, or an annual $\mathrm{P}$ demand of about $44 \mathrm{mmol} \mathrm{P} \mathrm{m}^{-2} \mathrm{yr}^{-1}$ (when extrapolated on the whole growth period). The DIP concentration in Arcachon Bay waters was very low at high tide from March to October (below $0.5 \mu \mathrm{M}$, data not shown), while the meadow, located in the inner bay, emerged several hours per day. The highest $\mathrm{P}$ uptake may occur through the roots, not through leaves (Holmer et al. 2006), and sedimentary redoxsensitive pools represent the most important $\mathrm{P}$ stock for growth. Assuming a root zone circumscribed to the first $6 \mathrm{~cm}$ of sediment, the annual dynamics of the particulate redox-sensitive $\mathrm{P}$ pool $\left(\mathrm{P}_{\mathrm{asc}}\right)$ can be estimated and compared with the unvegetated site (Fig. 5). In meadow sediments, this available $\mathrm{P}$ fraction increases from $90 \mathrm{mmol} \mathrm{\textrm {m } ^ { - 2 }}$ during the dormancy period (December) to $149 \mathrm{mmol} \mathrm{m}^{-2}$ during the growth period (in July) by binding processes with precipitated iron oxides, as described in the preceding paragraph. According to these calculations, these adsorption processes correspond for this period $(7 \mathrm{mo})$ to an increase

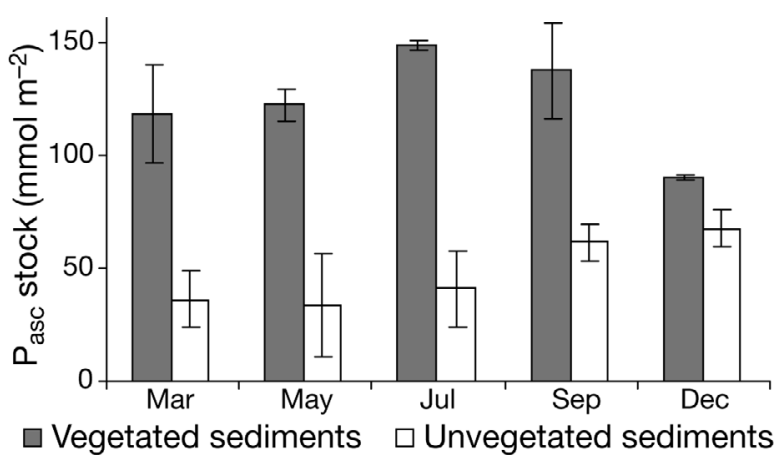

Fig. 5. Seasonal dynamics of the available P stocks (redoxsensitive $\mathrm{P}$ pool, extracted by ascorbate, $\mathrm{P}_{\text {asc }}$ ) in the top $6 \mathrm{~cm}$ of sediments at Stn Z (vegetated sediments) and Stn N (unvegetated sediments). Error bars indicate SDs $(n=21)$ 


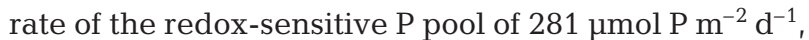
and this pool is formed by a DIP uptake from pore water (Figs. $2 \& 6$ ) and from the water column at high tide $\left(46 \mu \mathrm{mol} \mathrm{P} \mathrm{m}^{-2} \mathrm{~d}^{-1}\right.$, Figs. 4 \& 6). This $\mathrm{P}$ reserve is thus sufficient to support the annual $\mathrm{P}$ eelgrass demand, without signs of $\mathrm{P}$ limitation. However, Holmer et al. (2006) indicated that P limitation could occur if the P release from the particulate reactive pool is too slow to support maximum growth rates. In winter, plant assimilation drops and the redox-sensitive particulate $\mathrm{P}$ pool continues to decrease indirectly through the autochthonous organic matter degradation processes (e.g. reduction of iron oxides), inducing a DIP efflux from the sediment to the water column at
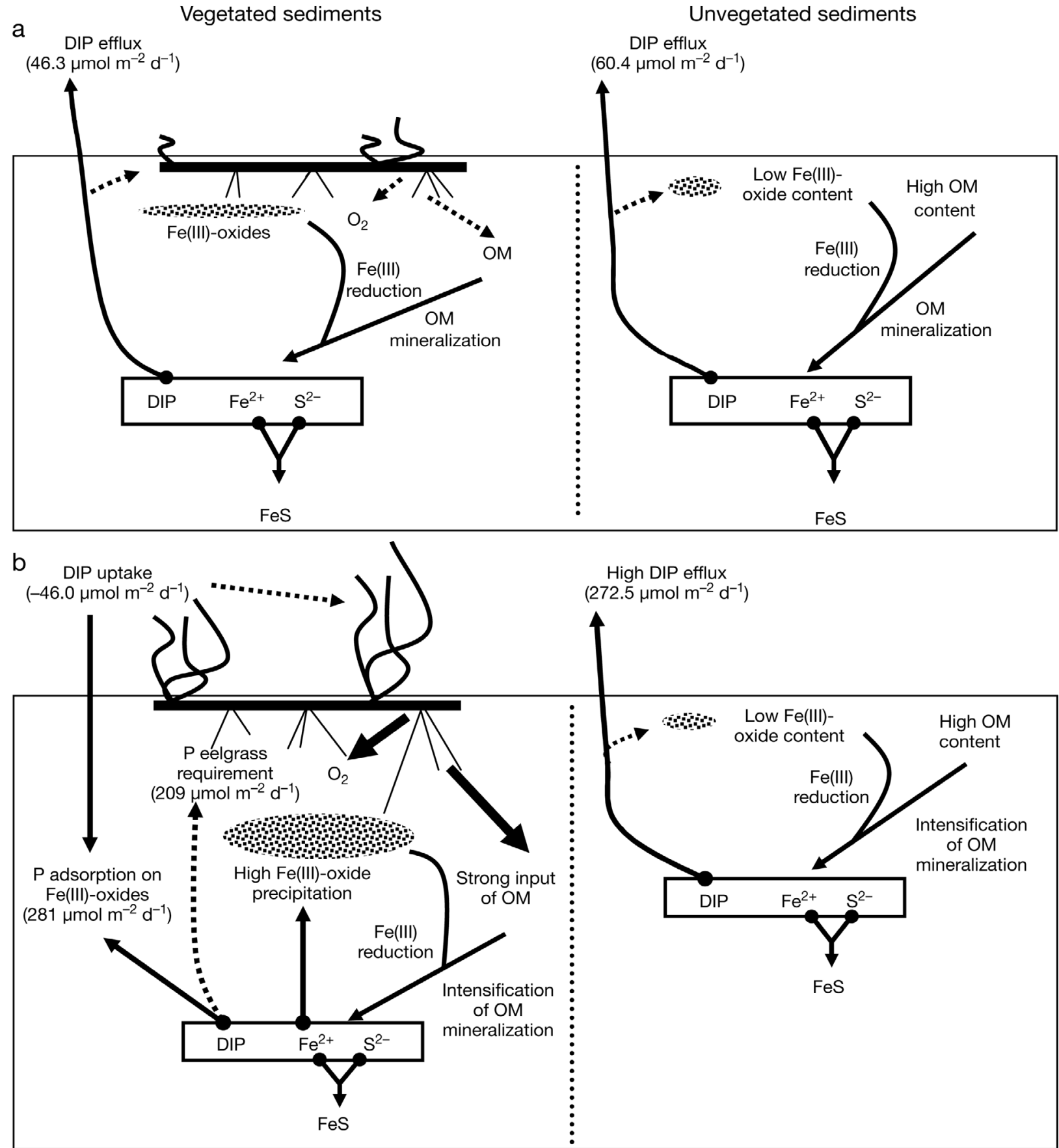

Fig. 6. Schematic representation of the P-Fe seasonal dynamics in the Zostera noltii meadow. (a) Dormancy period (e.g. December); (b) growth period (March to September). Fluxes to or from the water column were measured during immersion time (see Fig. 4). DIP: dissolved inorganic phosphorus; OM: organic matter 
high tide during the dormancy period (Figs. 4 \& 6). In unvegetated sediments, the environment stays strongly anoxic throughout the year, and the DIP efflux is also observed all year long. However, the benthic chamber measurements show that the DIP efflux drastically increases during the growth period (Fig. 4), probably by intensification of the mineralization processes and low Fe(III)-oxides precipitation during summer. Our data allow us to estimate that the redox-sensitive P pool decreases from $67 \mathrm{mmol} \mathrm{m}^{-2}$ in December to $34 \mathrm{mmol} \mathrm{m}^{-2}$ in May (Fig. 5), which represents a theoretical daily DIP release to pore water of about 220 $\mu \mathrm{mol} \mathrm{m} \mathrm{m}^{-2} \mathrm{~d}^{-1}$. This value is in agreement with our benthic chamber measurements in May $\left(272.5 \mu \mathrm{mol} \mathrm{m}{ }^{-2}\right.$ $\mathrm{d}^{-1}$, Fig. 4).

In Arcachon Bay, Zostera noltii meadows cover an area of $70 \mathrm{~km}^{2}$ with total production estimated at approximately $35.610^{9} \mathrm{~g} \mathrm{DW} \mathrm{yr}^{-1}$ (Auby \& Labourg 1996), corresponding to a total $P$ eelgrass requirement of ca. $3600 \mathrm{kmol} \mathrm{P} \mathrm{yr}^{-1}$. When extrapolating the available particulate $\mathrm{P}$ stocks measured in sediment of the meadow to the whole bay meadow, the interaction between the seasonal eelgrass dynamics and adsorption processes on iron oxides could provide at least about $4100 \mathrm{kmol} \mathrm{yr}^{-1}$ of $\mathrm{P}$ available from the redox-sensitive pool. This indicates that the eelgrass root cycle influences sediment redox properties, which act as a huge sink of DIP for the water column during spring. Then, the trapped $\mathrm{P}$ is on the whole sufficient enough to support the $\mathrm{P}$ requirement for $Z$. noltii growth. Thus, during the meadow decay period, the unused $P$ reserve could supply large amounts of DIP from the sediment to the pore water and diffuse to the water column.

The eelgrasses annual growth cycle is a dominant control of the redox chemistry of the surface sediment and consequently of phosphorus-iron cycles. The sediment oscillates from an oxic state near the eelgrass roots during the growth phase, to a completely reduced state at the periphery of the rhizosphere in the spring-summer or in the whole sediment layer during winter. During the growth season, roots provide oxygen to the sediments, and large amounts of water column and pore water DIP precipitate together with Fe(III)-oxide formation. The increasing loads of autochthonous labile organic matter released by roots to the sediment also induce a root zone with heterogeneous redox properties. Through these intense early diagenenic processes close to the roots, $\mathrm{P}$ from the redox-sensitive pool is released again, providing a sufficient source of DIP to eelgrasses essential for their growth, while Fe(II) reprecipitates with free sulphides in anoxic zone, or in the form of $\mathrm{Fe}$ (III)-oxides depleted in $\mathrm{P}$ in the root zone. Thus, while the meadow sediments act as a huge sink of DIP for the water column during the growth period, the opposite trend is observed in unvegetated sediments, where a net efflux of DIP to the water column is found due to mineralization processes. Therefore, the ratio between meadow surface and unvegetated surface is a major control parameter for the mass balance of phosphorus in the studied coastal lagoon.

Acknowledgements. We gratefully acknowledge M. V. Commarieu, S. Bujan, D. Poirier, A. Carasco and F. Guerin, who have contributed in different ways to this work. We also thank Dr. H. Etcheber for the particulate carbon and sulphur analysis, and N. Lavesque for his very helpful participation in benthic macrofauna sampling. We thank the 3 anonymous reviewers for useful critical and scientific comments. We express our gratitude to the municipality of Lanton (Arcachon Bay, France). This study was supported by the French National Programme on Coastal Environment (PNEC 'Chantier Littoral Atlantique') and the ANR project PROTIDAL.

\section{LITERATURE CITED}

Anschutz P, Zhong S, Sundby B, Mucci A, Gobeil C (1998) Burial efficiency of phosphorus and the geochemistry of iron in continental margin sediments. Limnol Oceanogr 43:53-64

Anschutz P, Chaillou G, Lecroart P (2007) Phosphorus diagenesis in sediment of the Thau Lagoon. Estuar Coast Shelf Sci 72:447-456

Auby I, Labourg PJ (1996) Seasonal dynamics of Zostera noltii hornem. In the Bay of Arcachon (France). J Sea Res 35:269-277

Azzoni R, Giordani G, Bartoli M, Welsh DT, Viaroli P (2001) Iron, sulphur and phosphorus cycling in the rhizosphere sediments of a eutrophic Ruppia cirrhosa meadow (Valle Smarlacca, Italy). J Sea Res 45:15-26

Blackburn TH, Nedwell DB, Wiebe WJ (1994) Active mineral cycling in a Jamaican seagrass sediment. Mar Ecol Prog Ser 110:233-239

Blanchet H, de Montaudouin X, Lucas A, Chardy P (2004) Heterogeneity of macrozoobenthic assemblages within a Zostera noltii seagrass bed: diversity, abundance, biomass and structuring factors. Estuar Coast Shelf Sci 61:111-123

Canfield DE, Thamdrup B (1996) Fate of elemental sulfur in an intertidal sediment. FEMS Microbiol Ecol 19:95-103

Cha HJ, Lee CB, Kim BS, Choi MS, Ruttenberg KC (2005) Early diagenetic redistribution and burial of phosphorus in the sediments of the southwestern East Sea (Japan Sea). Mar Geol 216:127-143

Duarte CM (1990) Seagrass nutrient content. Mar Ecol Prog Ser 67:201-207

Forja JM, Gomez-Parra A (1998) Measuring nutrient fluxes across the sediment-water interface using benthic chambers. Mar Ecol Prog Ser 164:95-105

Frederiksen MS, Glud RN (2006) Oxygen dynamics in the rhizosphere of Zostera marina: a two-dimensional planar optode study. Limnol Oceanogr 51:1072-1083

$>$ Goodman JL, Moore KA, Dennison WC (1995) Photosynthetic responses of eelgrass (Zostera marina L.) to light and sediment sulfide in a shallow barrier island lagoon. Aquat Bot 50:37-47

Gras AF, Koch MS, Madden CJ (2003) Phosphorus uptake kinetics of a dominant tropical seagrass Thalassia testudinum. Aquat Bot 76:299-315 
Gribsholt B, Kristensen E (2002) Effects of bioturbation and plant roots on salt marsh biogeochemistry: a mesocosm study. Mar Ecol Prog Ser 241:71-87

Hebert AB, Morse JW (2003) Microscale effects of light on $\mathrm{H}_{2} \mathrm{~S}$ and $\mathrm{Fe}^{2+}$ in vegetated (Zostera marina) sediments. Mar Chem 81:1-9

> Hemminga MA (1998) The root/rhizome system of seagrasses: an asset and a burden. J Sea Res 39:183-196

> Hemminga MA, Koutstaal BP, Soelen J, Merks AGA (1994) The nitrogen supply to intertidal eelgrass (Zostera marina). Mar Biol 118:223-227

Holmer M, Nielsen SL (1997) Sediment sulfur dynamics related to biomass-density patterns in Zostera marina (eelgrass) beds. Mar Ecol Prog Ser 146:163-171

Holmer M, Carta C, Andersen FO (2006) Biogeochemical implications for phosphorus cycling in sandy and muddy rhizosphere sediments of Zostera marina meadows (Denmark). Mar Ecol Prog Ser 320:141-151

Isaksen MF, Finster K (1996) Sulphate reduction in the root zone of the seagrass Zostera noltii on the intertidal flats of a coastal lagoon (Arcachon, France). Mar Ecol Prog Ser 137:187-194

Jensen HS, Mortensen PB, Andersen FO, Rasmussen E, Jensen A (1995) Phosphorus cycling in coastal marine sediment, Aarhus Bay, Denmark. Limnol Oceanogr 40:908-917

Jensen SI, Kühl M, Glud RN, Jorgensen LB, Priemé A (2005) Oxic microzones and radial oxygen loss from roots of Zostera marina. Mar Ecol Prog Ser 293:49-58

Jézéquel D, Brayner R, Metzger E, Viollier E, Prevot F, Fievet F (2007) Two-dimensional determination of dissolved iron and sulfur species in marine sediment pore-waters by thin-film based imaging. Thau lagoon (France). Estuar Coast Shelf Sci 72:420-430

Jørgensen BB (1982) Mineralization of organic matter in the sea bed: the role of sulphate reduction. Nature 296:643-645

Kaldy JE, Eldridge PM, Cifuentes LA, Jones BW (2006) Utilization of DOC from seagrass rhizomes by sediment bacteria: ${ }^{13} \mathrm{C}$-tracer experiments and modeling. Mar Ecol Prog Ser 317:41-55

Kostka JE, Luther I, George W (1994) Partitioning and speciation of solid phase iron in saltmarsh sediments. Geochim Cosmochim Acta 58:1701-1710

Lee KS, Dunton KH (2000) Diurnal changes in pore water sulfide concentrations in the seagrass Thalassia testudinum beds: the effects of seagrasses on sulfide dynamics. J Exp Mar Biol Ecol 255:201-214

Leuschner C, Landwehr S, Mehlig U (1998) Limitation of carbon assimilation of intertidal Zostera noltii and Z. marina by desiccation at low tide. Aquat Bot 62:171-176

Lillebo AI, Flindt MR, Pardal MA, Marques JC (2006) The effect of Zostera noltii, Spartina maritima and Scirpus maritimus on sediment pore-water profiles in a temperate intertidal estuary. Hydrobiologia 555:175-183

Madureira MJ, Vale C, Goncalves MLS (1997) Effect of plants on sulphur geochemistry in the Tagus salt-marshes sediments. 4th International Symposium on the Biogeochemistry of Model Estuaries. Mar Chem 58:27-37

> McGlathery KJ, Berg P, Marino R (2001) Using porewater profiles to assess nutrient availability in seagrass-vegetated carbonate sediments. Biogeochemistry 56:239-263

McRoy CP, Barsdate RJ, Nebert M (1972) Phosphorus cycling in an eelgrass (Zostera Marina L.) ecosystem. Limnol Oceanogr 17:58-67
Murphy J, Riley JP (1962) A modified single solution method for determination of phosphate in natural waters. Anal Chim Acta 27:31-36

Oremland RS, Taylor BF (1977) Diurnal fluctuations of $\mathrm{O}_{2}, \mathrm{~N}_{2}$, and $\mathrm{CH}_{4}$ in the rhizosphere of Thalassia testudinum. Limnol Oceanogr 22:566-570

Papadimitriou S, Kennedy H, Rodrigues RMNV, Kennedy DP, Heaton THE (2006) Using variation in the chemical and stable isotopic composition of Zostera noltii to assess nutrient dynamics in a temperate seagrass meadow. Org Geochem 37:1343-1358

Perez-Llorens JL, Niell FX (1993) Seasonal dynamics of biomass and nutrient content in the intertidal seagrass Zostera noltii Hornem, from Palmones River estuary, Spain. Aquat Bot 46:49-63

Perez-Llorens JL, Niell FX (1995) Short-term phosphate uptake kinetics in Zostera noltï Hornem: a comparison between excised leaves and sediment-rooted plants. Hydrobiologia 297:17-27

Phillips RC, Menez EG (1988) Seagrasses, Vol 34. Smithsonian Institution Press, Washington, DC

Ruttenberg KC (1992) Development of a sequential extraction method for different forms of phosphorus in marine sediments. Limnol Oceanogr 37:1460-1482

Sand-Jensen K, Prahl C, Stokholm H (1982) Oxygen release from roots of submerged quatic macrophytes. Oikos 38:349-354

Smith RD, Pregnall AM, Alberte RS (1988) Effect of anaerobiosis on root metabolism of Zostera marina (eelgrass): implications for survival in reducing sediments. Mar Biol 98:131-141

Stookey LL (1970) Ferrozine-a new spectrophotometric reagent for iron. Anal Chim Acta 42:779-781

Strickland JDH, Parsons TR (1972) A practical handbook of seawater analysis. Fisheries Research Board of Canada Bulletin 167. Fisheries Research Board of Canada, Ottawa

Sundby B, Gobeil C, Silverberg N, Mucci A (1992) The phosphorus cycle in coastal marine sediments. Limnol Oceanogr 37:1129-1145

Sundby B, Vale C, Cacador I, Catarino F, Madureira MJ, Caetano M (1998) Metal-rich concretions on the roots of salt marsh plants: mechanism and rate of formation. Limnol Oceanogr 43:245-252

Sundby B, Vale C, Caetano M, Luther GW III (2003) Redox chemistry in the root zone of a salt marsh sediment in the Tagus Estuary, Portugal. Aquat Geochem 9:257-271

Thouzeau G, Grall J, Clavier J, Chauvaud L and others (2007) Spatial and temporal variability of benthic biogeochemical fluxes associated with macrophytic and macrofaunal distributions in the Thau lagoon (France). Estuar Coast Shelf Sci 72:432-446

Tréguet P, Le Corre P (1975) Manuel d'analyse des sels nutritifs dans l'eau de mer. Utilisation de l'AutoAnalyseur II Technicon, 2nd edn. Laboratoire de Chimie marine, Universite de Bretagne Occidentale, Brest (in French)

Walker DI, Campey ML, Kendrick GA (2004) Nutrient dynamics in two seagrass species, Posidonia coriacea and Zostera tasmanica, on Success Bank, Western Australia. Estuar Coast Shelf Sci 60:251-260

Welsh DT, Bartoli M, Nizzoli D, Castaldelli G, Riou SA, Viaroli P (2000) Denitrification, nitrogen fixation, community primary productivity and inorganic-N and oxygen fluxes in an intertidal Zostera noltii meadow. Mar Ecol Prog Ser 208: $65-77$

Submitted: July 2, 2007; Accepted: September 13, 2007

Proofs received from author(s): February 6, 2008 